\section{Restless Containers: Thinking interior space - across cultures}

\section{A.-Chr. Engels-Schwarzpaul}

In Innenraum denken (Thinking Interior Space), a section in the first volume of his Spheres trilogy (1998, 1999b, 2004), German philosopher Peter Sloterdijk describes human relations as being akin to containers that restlessly enclose and exclude each other (1998: 85). To him, humans are "wild interior architects", labourers who incessantly craft their lodgement in imaginary "sonorous, semiotic, ritual, [and] technological containers" (1998: 84). While producing their own enclosures, they are no less encompassed in those of others, into which they are unavoidably thrown upon leaving that most primal of spheres, the womb. In this way, Sloterdijk's positing of a complex overlapping landscape of containment and containing unsettles crude inside/outside divisions. Internationally, he is held to be a philosopher who has returned questions of ontological being, or being-in-the world, to a spatial arena: being-in-the world is being-in-space. Co-existence (Mit-Sein) precedes existence (Dasein). The sense of self pervading Sloterdijk's explorations is essentially plural. ${ }^{1}$ The individual is never alone.
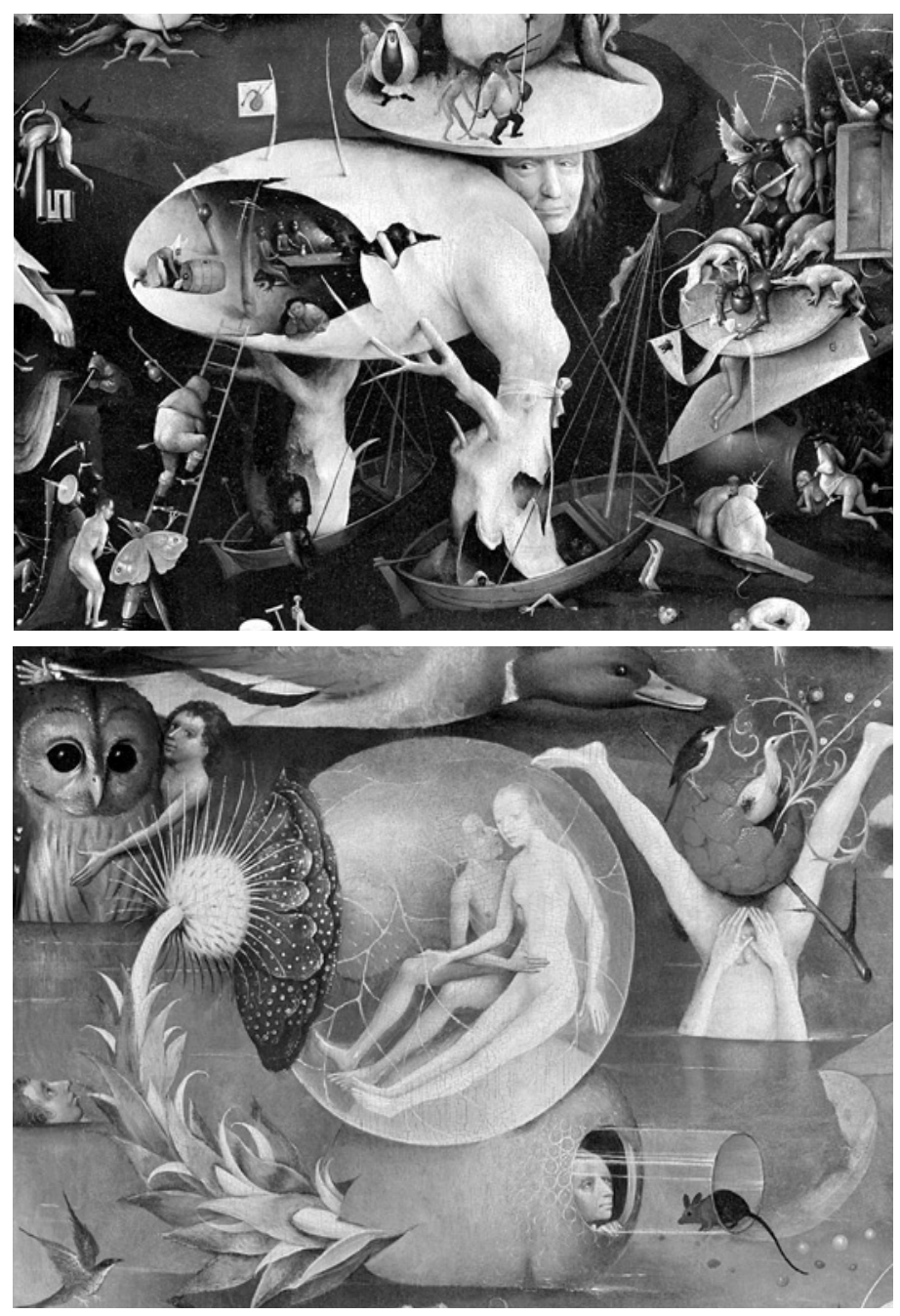

Both images: Hieronymus Bosch The Garden of Earthly Delights (ca. 1490 to 1510 , details). Wikimedia Commons

\author{
I gratefully acknowledge the help of Moana \\ Nepia, Albert Refiti and Ross Jenner, who \\ commented on earlier drafts, and of the \\ anonymous reviewers. My thanks to Andrew \\ Douglas for his fine editing. All translations \\ from German texts are mine. \\ 1 Sloterdijk is not the only Western philo- \\ sopher who explores how alternative notions \\ of self can reconnect the isolated individual \\ with the social and natural world (see, for \\ instance, Nancy 2007). Post-structuralist \\ approaches generally dissociate agency and \\ control from the masterful intentionality of \\ the Ego, and these shifts could constitute a \\ potential rapprochement with non-Western \\ notions of self. Sloterdijk, though, makes \\ more explicit connections between forms of \\ self and spatial relationships. The first volume \\ of Spheres, Bubbles: Microspherology (W. \\ Hoban, Trans.) is to be published by MIT \\ Press in October 2011.
}


Sir John Everett Millais, Bubbles (1886). Photo: Bob Swain

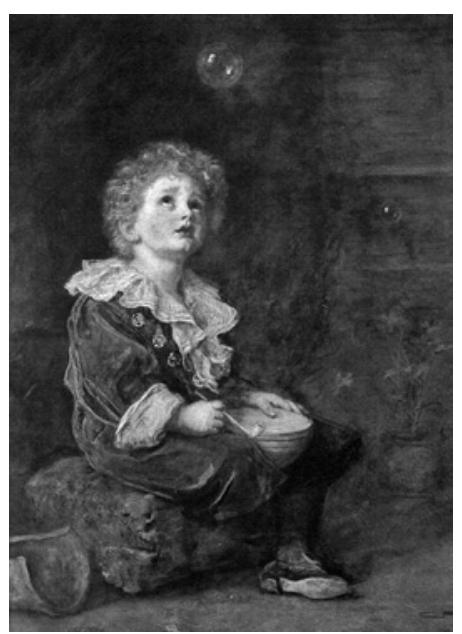

With its emphasis on the plurality of the self and the inclusion of non-human agents, Sloterdijk's theoretical position - though not widely known or discussed in Aotearoa/New Zealand - is fertile ground for the investigation of spatial relationships, as I aim to show. In this paper, I propose, with Sloterdijk, that a correlation necessarily exists between a culture's prevailing sense of selfhood in relation to others (Dasein and Mit-Sein) and the predominant spatial relationships it crafts. I also aim to interrogate the validity of his observations beyond the European sphere where they have been developed. When brought into productive tension with Māori and Pacific spatial relationships, aspects of Sloterdijk's thought may elucidate implicit codes of inclusion and exclusion and, in turn, better help us understand current spatial patterns and perhaps their future unfolding. Aotearoa/ New Zealand - established in the encounter of two parties with disparate ideas of self - today comprises many cultural groups, all with varying relationships between self and world. This is what we need to understand better at a spatial level.

Certainly Sloterdijk allows us to see past the prevailing, narrow depiction of interior and exterior relationships centred on the nineteenth-century, bourgeois individual - something succinctly canvassed by Walter Benjamin, for instance. In fact, this individual sense of self began to replace a more collective one in Western societies during what Sloterdijk calls "terrestrial globalisation" (1492-1974). Just as imperial/colonial agents ventured out into foreign exteriors, drawing in turn new contours for imperial territorial interiors, a particular form of private interiority arose, one capable of both recognising and closing out colonial others. Moreover, the division of the world into an inside (to which the self and its possessions belong) and an outside (of the other, the foreign, the yet to be taken possession of) takes on a curious configuration in 'postcolonial' settler societies where the erection of 'private interiors' was undertaken within a broader domain of colonial exclusion. In these settings, globalisation as colonisation continues - rather than being overcome, as Sloterdijk holds - if 'overseas' theories are imported without critical questioning. In settler societies, in particular, the relevance of theories generated elsewhere can only be established in relation to indigenous constellations.

By considering Sloterdijk's project in the context of Aotearoa, I hope to compose a more nuanced understanding of colonial and indigenous spatiality. To these ends the paper falls into three parts: the first provides an overview of a selection of Sloterdijk's thoughts on interior and exterior realms; the second considers specific Māori and Pasifika spatial notions and practices; and the third will pursue a synthesis of these divergent approaches resulting in what I propose to call interpretation of the 'in'.

\section{Sloterdijk's Spheres: European forms of interiority}

In Spheres, spatiality plays a pivotal role. Whether people feel enveloped in the world as in a perfect, God-given sphere or look at it from the outside affects their state of being and shapes their relationship with a world at large. Blasen (Bubbles, the first volume of Sphären) opens with the scene of a child on a balcony blowing soap bubbles and feverishly watching them float into the open. Whenever one bursts, Sloterdijk says, there remains in its place, for an instant, the lonely "soul, which had left the body of the blower" - no longer contained in an exclusive connection between bubble and blower but in an 'outside-itself' relation with the world (1998:18). Likewise, what Martin Heidegger called Dasein (Being) participates in extension. We arrive, in Stuart Elden and Eduardo Mendieta's words, in the world as "mangled creatures" and survive only due to the "generosity and 

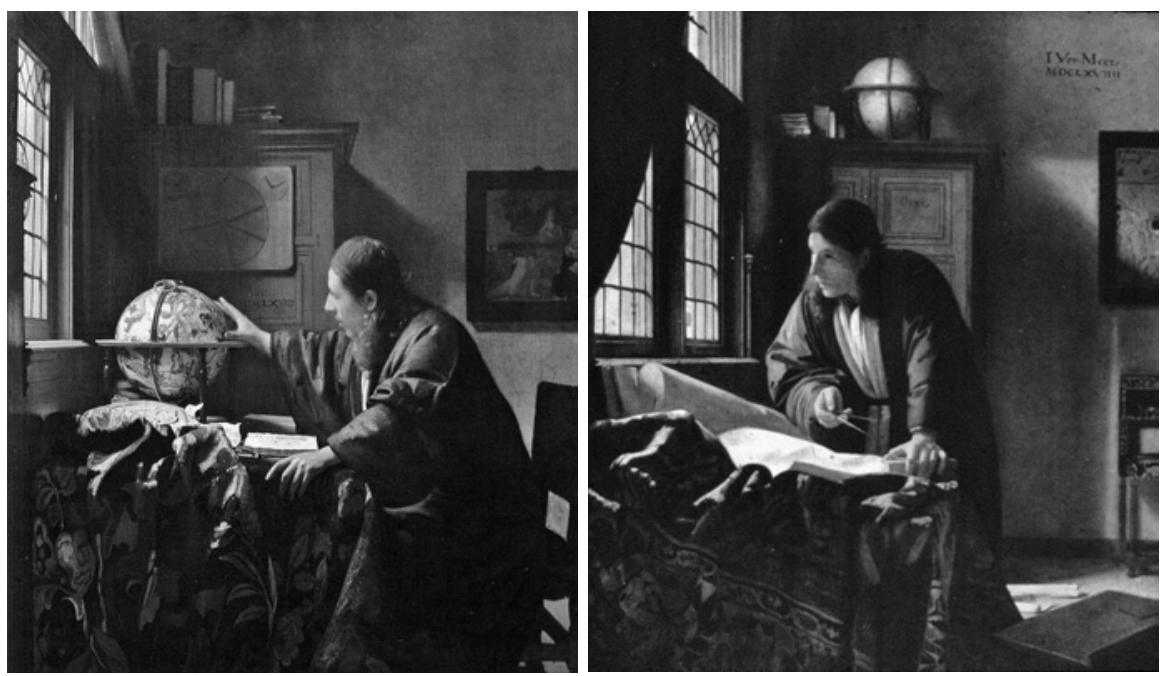

gratitude" of others who welcome us, nourish us, give us "an abode and refuge". As they say, we are "born of someone, [and...] someone receives us" (2009: 6).

Spheres in Sloterdijk's account are symbolic as much as they are material: beingin-spheres is a principal human condition (1998: 14) and, thus, solidarity and MitSein (being-with) begin in the womb (2005: 403). Similarly, human beings are constantly overlapping with, and being contained in, various worlds with others (2005: 223). Coming from an inside, they never cease to design these existential spaces as interiors of some sort. Hence, strong relationships of closeness and participation in graduated spheres of sonorous, sensual, semiotic and material intimacy are pivotal for articulating and maintaining being-in and being-with. Nevertheless, this inside-ness is - from the beginning - touched by an exterior against which it must assert itself, by way of sustained repair and expansion (Sloterdijk 1998: 14).

The second volume of Spheres, Globen (Globes, 1999), traces the expansion of what Sloterdijk calls the soul's microspheric bubbles into the macrospheres of globes. Europe's relationships with the world, he asserts, changed when a belief in the earth's flatness in the Middle Ages acquired again a spherical sense. The construction of the first world globe in 1492 pointed to an emerging tendency of lookingat-the-world, of thinking in terrestial, particularly spherical terms. Between the seventeenth and nineteenth centuries, it was not uncommon in paintings of European interiors depict globes, for instance in Vermeer's Geographer (1668-9). For Sloterdijk, this was indicative of a shift away from a commonly shared sense of being-in-the-world to one concerned with looking-at-the-world as if from an external perspective (2005: 43-4). With increasing colonisation ("terrestrial globalisation"), the exterior became a privileged site from which to secure the future - the space into which Europeans ventured as explorers, traders and travellers. Yet this world (without periphery, with its centre everywhere, neither womb nor container and unbounded on all sides) could no longer provide shelter as earlier spatial conceptions had. Imperial pioneers increasingly sought to save their souls by retreating into their richly decorated and wallpapered interiors (Sloterdijk 2005: 147, 54). ${ }^{2}$ When the modern political order was established in the eighteenth century, the separation between a world out-there and the inner province of the self instituted earlier by René Descartes was strengthened and subsequently sedimented into bourgeois values of interiority. In the nineteenth century, homes and workplaces were increasingly separated (Perrot 1990: 9-10), and the interior itself became a defence against the "noise, activity, and threats of the street, the space of the
Johannes Vermeer The Astronomer (1668) and The Geographer (1668-9). Photos: Bob Swain
2 Benjamin observed how the nineteenthcentury intérieur turned into an étui, a receptacle in which "self-satisfied burgher[s]" wove "a dense fabric" about themselves like a "spider's web", and in which world events were hung "loosely suspended" (Benjamin 2002: 221). The home became the stage for a new personality of the private individual (Cohen 2006: 136). Divorced from communal life, people assembled "remote locales and memories of the past" as if their living room were boxes "in the theatre of the world" (Benjamin 2002: 19). Increasingly, the exterior was watched "from a space deep within the bourgeois interior" (Alford 2002: 245). Mirrors regulated the interpenetration of interiority and world in different ways - reflecting, perhaps, culturally divergent senses of self: they interwove spaces in French cafés by bringing "the open expanse, the street" inside and depriving the wall of its significance "as a container of space" (Benjamin 2002: R1,1 and $\mathrm{R} 2 \mathrm{a}, 1$ ). 

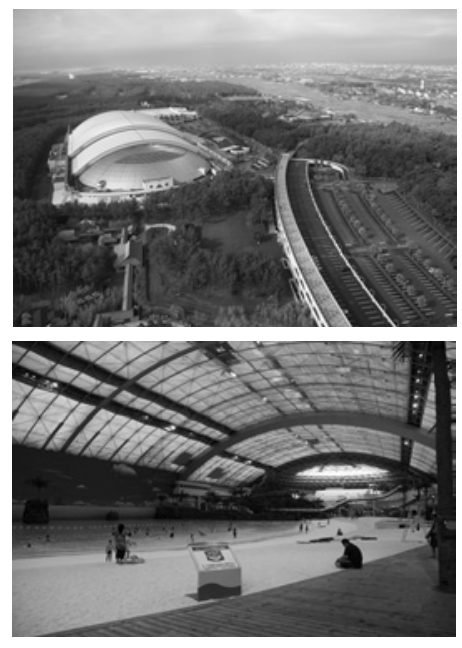

Miyazaki Ocean Dome (SeaGaia), Japan, interior and exterior (2007).

Photos: Max Smith

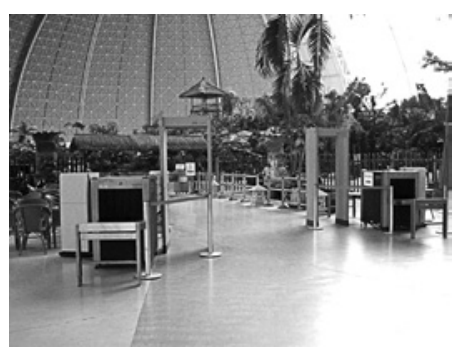

Entrance to Tropical Islands Resort, Brandt, Germany (2006). Photo: author

3 "Immunisation is the construction of protective tissue as a prevention against invaders and insulters." (Mönninger 2009: 9)

4 The political aspects of space were very obvious in Europe during the inter-war period but after WW2 space was depoliticised. From the late 1950s, accompanying a gradual saturation of the European markets, 'space' became increasingly an architectural and interior design concept. A "philosophy of the House Beautiful" developed, in which space is no longer an existential question but a luxury commodity. See Günzel (2005: 103) and Sloterdijk is this issue. masses" (Gunning 2003: 106). Over time, this concept of interiority became central to Western self-understanding. Today, it is hard to unsettle and colours completely our notions of inside and outside, occluding a diversity of spatial relationships.

The third volume, Schäume (Foams, 2004), considers the current phase of globalisation, which for Sloterdijk is characterised by the virtualisation of all relationships and a resulting fundamental spatial crisis. As previously cohesive spheres were shattered and our globe lost its central position in the universe during the Copernican revolution, a singularly globalised world came into being. Sloterdijk argues that, to define their identity and location, ethnic and national groups rely on tangible and symbolic boundaries that elaborate significant differences between inside and outside (1999a: 28). These differences are gradually eroded by the effects of globalisation. New types of space proliferate in polycentric constellations, in which each bubble or sphere, while enclosed in itself, in fact depends on its neighbour. Simultaneously, large-scale "luxury hothouses" and "atmospheric islands" (resorts, gated communities, shopping malls, etc.) form isolated clusters that fundamentally resist (neighbourly) exchange. These literalisations of an island mentality model for Sloterdijk the operation of micro-worlds within worlds, much as maritime boundaries keep both the exterior out and draw together a defended or resistive interior (in a geographic sense, with flora, fauna, and human populations with their specific and local cultures, 2004: 311). In this sense, most, if not all, human beings are unwitting island dwellers insofar as they live within particular locations and cultures, which are isolated by their own physical or semantic 'atmospheres' in Sloterdijk's terms (313). Curiously, "island” and "apartment building” share a Latin etymology - insula (339); even single houses or apartment blocks function as immune systems that protect "an area of well-being against invaders and other carriers of malaises" (535). With their tendency towards defensive closure, they demonstrate that openness towards the world is always complemented by a simultaneous turning-away-from it (540).

Perhaps the first built atmospheric island, Paxton's Crystal Palace at the 1851 Great Exhibition in London, was not only the "largest greenhouse ever built, ... a climate-controlled reconciliation of Arcadia and industry" (Wollen 1993: 9), but instantiated a new form of interiority: glasshouses and hothouses, theme-parks and resorts (Sloterdijk 2004: 342). Emerging towards the end of Sloterdijk's "terrestrial" globalisation, and gaining more and more currency today during "electronic" globalisation, luxury hothouses like the Ocean Dome in Miyazaki (Japan) seek to be total installations. Ideally, visitors forget that they are visitors (814) and feel fully immersed, within a securely enveloping interiority that has otherwise been lost everywhere but in the private dwelling. As islands though, these installations rely on consolidated and policed boundaries to keep dissenters and interlopers out, to uphold "an eternal spring of consensus" (Sloterdijk 2005: 267). These "great indoors of capitalism" (Couture 2009: 161) come to interiorise more and more of the world: "what used to be environment is now enclosed in biospheric hothouses" (Mönninger 2009: 9). ${ }^{3}$ Space, so contested in the nineteenth and early twentieth centuries, became depoliticised in Europe after WW2 and, in the global interior formed by capitalism, architectural and interior design in turn came to service a luxury hothouse for the privileged third of humanity (Sloterdijk 2005: 303). ${ }^{4}$ This luxury environment, however, is haunted by political and economic refugees (Günzel 2005: 103) who are feared by all who are not ready to embrace the chances and risks of a globe with thin walls and mixed populations (Sloterdijk 1999a: 28).

In the Spheres' three volumes, Sloterdijk develops aspects of being-together, from Sein to Mit-Sein. To explore the "co-existence of people and things in connective 
spaces”, he continually turns to spatial metaphors and concrete building practices. For, as he says, a house is a tenuously constructed "three-dimensional answer to the question of how someone can be together with someone, and something in something" (2009). The fragile nature of our coexistence in the world needs to be re-evaluated. The interior, abandoned by many architects as an inconsequential aspect of practice, is one such fragile category calling for re-evaluation. The interior deserves our defence, for only with a certain degree of embeddedness in an enveloping sphere can we fully relate to and move in the exterior. On the other hand, when stereotypical divisions between interior and exterior materialise in attitudes and actions ("inside" is one's own and good, "outside" a bad exterior belonging to others: foreigners, immigrants, refugees who do not share one's own group's beliefs), the interior of one's dwelling can become the locus from which the impure, threatening and foreign are projected onto the exterior, where they are persecuted and combated (Funke 2006: 245). Cultures and institutions are containers that grow out of human individuals and groups. They contain their makers, in turn. Language, for instance, often serves as "a staunch fortress in which we can ward off the open" (Sloterdijk 2009).

\section{Inside the fortress, held captive}

What is closest and most familiar to us is precisely what we do not see. Ludwig Wittgenstein remarked that when we believe we are "tracing the outline of [a] thing's nature over and over", we are often "merely tracing around the frame through which we look at it. A picture [holds] us captive" - we cannot "get outside it, for it [lies] in our language and language seem[s] to repeat it to us inexorably" (1958: \#114). Sloterdijk, even though he is familiar with several non-European epistemologies - and refers to such forms of knowledge frequently - ultimately cannot get outside a Eurocentric story about the world. This then comes to represent the history of the world in his writing. For instance, in Im Weltinnenraum, he suggests that "humankind" only came into existence after hundreds of years of unilateral European travels, which opened up an "anthropological horizon of the plenum of people and cultures" (2005: 222). ${ }^{5}$ This could not but sound incongruous to Pacific peoples, whose ancestors (the "most daring navigators in the history of humankind”, Kroeber-Wolf \& Mesenhöller 1998: 314) undertook extensive and complex sea voyages thousands of years in advance of the Europeans. And, while Sloterdijk describes convincingly how Europeans explorers and colonists carried with them their own spatial imagination and structures (2005: 193), he does not consider that these may not have been taken up by 'the natives' to become shared concepts. Likewise, Sloterdijk assumes that European colonisers were better at observing than 'natives' (i.e., perceiving "the Other through a theoretical window" and eluding "counter observation", 194). And while he explains how European theoretical perspectives framed the 'Other' during colonisation, he does not consider how native theories may have been deployed to observe and frame the colonisers, nor in fact how they have been picked up subsequently by these same colonisers to understand their shifted place in the world. ${ }^{6}$ Sloterdijk's otherwise insightful narrative about the crucial role of lived space (2005: 11) suffers as a consequence. No doubt, grand narratives, if they avoid "intolerable simplifications" (13), can shed light on particular historical moments, but a problem arises when they treat other cultures as something that can be beheld objectively - in other words, as something their author looks at, rather than lives in.

Thus, despite Sloterdijk's lucid articulation of Western modes of inclusion and exclusion, the dramatic, original difference between inside and outside he posits (1998: 84) plays out in his own work as specific divisions between "with-us and

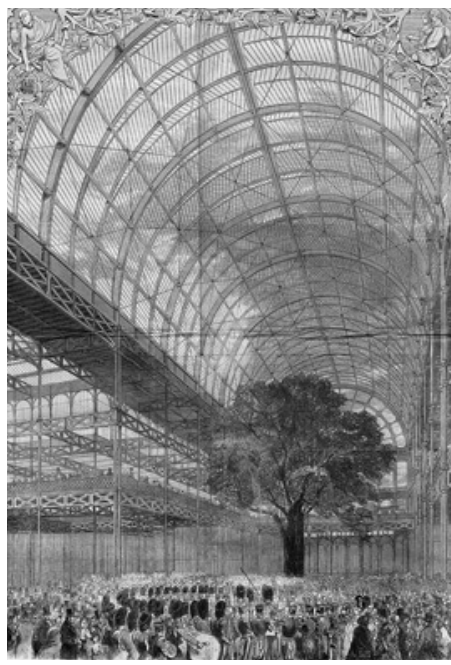

The Last Promenade at the Crystal Palace, from Illustrated London News (1852)

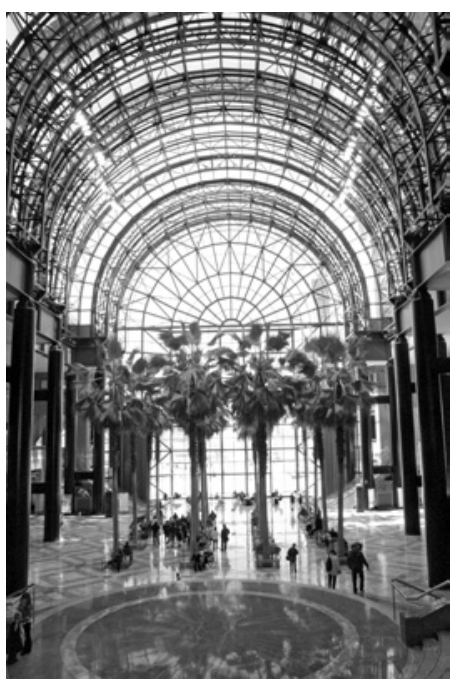

World Financial Center Winter Garden (2007). Photo: Francesco Federico
5 Sloterdijk shifts towards more consciously Eurocentric positions over the years that lie between the first volume of Sphären and Im Weltinnenraum.

6 For the obverse argument, see Ray Chow, who claims that the native's gaze renders the coloniser self-conscious and thus produces him as subject (Chow 1993: 52). 
not-with-us” (Mönninger 2009: 5). The resulting, and presumably unwitting marginalisation of other knowledges may well be a reason why he does not explore the function and effects of such central concepts as "with" and "in" in non-European contexts. Certainly for some commentators, Sloterdijk's account of the modern world is "hemmed in by propositions about the nature of evidence and cultural preconceptions about space” (Thrift 2009: 127).

These objections aside, Sloterdijk usefully speaks of half-open containers, and of the horizon as "an open circle that allows [us] to live in a sort of ecstatic interior", one that provides us with a provisional opening to the world (Sloterdijk \& Royoux 2005: 232). Along these lines, he draws on Gaston Bachelard who conceived of humans as fundamentally unsettled and half-open beings (1969: 222). This halfopenness at the core of our being always allows inside and outside to be reversed. Accordingly, the containers that house us, as mutable constellations, elude simple spatial demarcations and multiply as unexpected, fragile spheres with varying shades of interiority.

With this in this mind, I will now juxtapose Sloterdijk's decidedly European notions of space with those of Aotearoa and the Pacific to see if the boundaries (Samoan: $t u a^{\prime} o i$ ) between them can make good neighbours (tua'oi). In this, I am specifically interested in collective senses of self and corresponding forms of interiority. Therefore, my account of Pacific spaces will focus on what Sloterdijk calls Kollektoren (collectors, buildings that gather), houses that have performative aspects and provide the conditions for the production of collective space: the Māori wharenui (great, or meeting house) and the Samoan faletele (great, council house).

\section{Selves, ancestors, land, seas and skies: Pacific forms of interiority}

As a persistent critic of Western individualist autonomy, Sloterdijk emphasises the extent to which human relationships are not optional, nor revocable. He considers the dream of a subject "who observes, names and owns everything, without being contained, named and owned in turn", a fundamental neurosis of Western cultures.

Doggedly returns the dream of an all-inclusive monadic sphere, whose radius would be one's own thinking - a thinking that traverses effortlessly its spaces to the extreme periphery, gifted with a dreamlike, casual discursivity which no real, external thing can resist. (Sloterdijk 1998: 86)

Conversely, as Sloterdijk insists, subjects arise in proximities with other "restless containers"; they contain and exclude each other; they ensconce themselves not only in their own symbolic orders but are part of a shared cosmos. Space arises from a participatory folding and entangling of interior and exterior. To think of interior and exterior, and likewise of individuals, as principally separate is to avoid the ecstatic intertwining in a shared interior that produces strong relationships (Sloterdijk 1998: 84-5).

These views have great affinity with Pacific space-relations. For instance, the current Samoan Head of State, Tui Atua Tupua Tamasese Efi, affirms that Samoans "live not as individuated beings but as beings integrally linked to their cosmos, sharing divinity with ancestors, land, seas and skies" (2007). Samoans live in reciprocal relationships of belonging with their family, their village, and their nation and these relationships are the essence of their sense of belonging (2007) and, thereby, their identity. These inclusions form a vast total space, a spiritual 
and material world that is affirmed through local relational knots and nodes ( $v \bar{a}$ fealoaloa'i), and according to shared boundaries (tua'oi) and thresholds (faitoto'a).

In contrast to continental Europe, Aotearoa and Samoa are both islands. A close relationship with the sea is perhaps one reason why wharenui and fale were historically mobile, rather than intended to last without change. ${ }^{7}$ As in other Pacific cultures, the prevailing Māori and Samoan sense of self is plural, or collective. The individual never completely emerges free from a greater whole and eventually in death is subsumed by it again. Relational Pacific spatial patternings produce their own material configurations and conditions of interiority. Thus, space, rather than being considered an empty container waiting to be filled, is dynamically generated between people - a notion Sloterdijk would no doubt find agreeable. The relationship between interior and exterior is mutable, like the fall of waves on a beach: a boundary manifests itself, but it is never constant nor the same. What is excluded at one time may be included at another. Māori and Samoan foldings of interior and exterior, particularly threshold zones, are articulated and varied across time, their boundaries articulated by ritual as extended, intensive events that cost time. They entail absolute or gradual inclusions and exclusions, even in the same person, who may undergo a change of being upon encountering thresholds. Māori and Samoan houses are co-determined by their relationship to the open ground in front, the marae atea or malae, the centre of collectiveness towards which they are orientated. In harsher climatic conditions, the entirely open space of the faletele, however, became in Aotearoa the wharenui's mahau, the porch which mediates between the whare's intense interior and the openness of the marae.

\section{Inside the ancestor - outside the pa}

In He tataitanga ahua toi (2006), Māori artist and theorist Robert Jahnke comments repeatedly on the conceptual and physical relationship between inside and outside. This relationship stems from a world-view "in which a spiritual dimension impacted on all spheres of the tribal interaction with their universe", a model "of space and time that conceptualised movement as a transition" through multiple tangible and intangible, spatial and temporal planes simultaneously; each transition was, by his account, "qualified by intersecting indices" (2006: 57). Therefore, the physical transition across the threshold of a whare is marked by "multiple metaphysical indices of inside and outside, above and below, front and back in terms of space and time simultaneously" in an "intimate connection between the material and spiritual world" (58). ${ }^{8}$

In the wharenui, there is at times an intense sense of interiority (e.g., a concentration on the interior, and a focus on events and discussions inside the house and on a collective self, rather than things outside). The house is the body of an ancestor (male or female), in whose belly or bosom the descendants and their associates are protected. The house "brings together its individual members into a united organism sharing life and a common heritage" (Harrison 1988: 1). ${ }^{9}$ A succession of thresholds, both physical and ritual, impart a changed quality to the interior, which is construed in opposition to the openness of the marae atea. While, in the past, the absence of windows other than the matapihi in the front could be explained by the lack of glass, it is striking that contemporary wharenui still maintain this sense of inwardness. However, this is not a private interiority; insofar as it is collective, it is communal and frequently overtly political and controversial - but tempered by the maxim that inside the house debates are to be constructive.

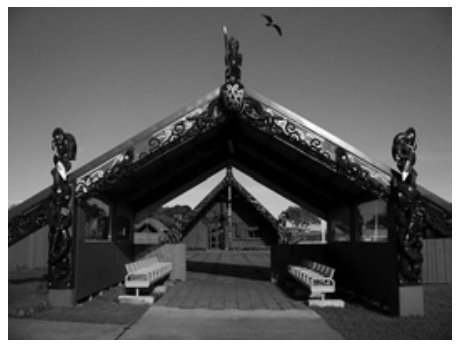

Waha roa at Orakei Marae, Auckland (2003). Photo: Carol Green
7 When Sloterdijk states that most, if not all human beings are unwitting island dwellers, he speaks as someone whose home is not an island and whose audience are not usually islanders. Is his choice of metaphor motivated by the seemingly (at least horizontally) clearcut original separation of an island from its environment? As he recounts in Foams, the island metaphor served as remote stageset for revisionary processes against the definitions of reality on European terra ferma (Sloterdijk 2004: 309); see also (ten Bos 2009). For a similar argument from a local perspective, see Austin (2004).

8 Jahnke refers to the pataka taonga (storehouse of precious objects) here, as an architectural example of this multidimensional concept. A similar statement could be made about the wharenui.

9 "The meeting house (whare whakairo) is conceptualised ... as a human body, usually representing the eponymous ancestor of a tribe. At the apex of the gable, attached to the tahuhu or ridgepole is the koruru (head). The maihi (bargeboards) are the arms, outstretched to welcome guests. The tahuhu is the backbone and the heke (rafters) are ribs. People in the house are protected in the bosom of their ancestor... The kuwaha (mouth) or door is the symbolic entry where the physical and spiritual realms come together. The window becomes the eye (matapihi) and the interior the womb (koopu). The poupou (carved posts) ... depict notable descendants from the eponymous ancestor ... reinforce the spiritual unity with human forebears right back to the beginning." (Harrison 1988:1) For an introduction to Māori houses, see Rau Hoskins in Mackenzie \& Bennett (2011a, 2011b) and a review of the series by Carin Wilson in this issue (p.133). 
10 Like the historical pa (fortified settlement), the contemporary marae complex is usually fenced in, but whereas the pa palisades were designed to keep out warring enemies, the boundaries of the mara preserves and protects a Māori space within a nation state which is, in the view of most Māori, controlled by Pākehā. The marae grounds are frequently the last piece of land still collectively owned by a hapū (sub tribe) the surrounding productive land being usually privately owned by Pākehā. The waha roa (entrance gate) as threshold has the function of setting in motion a Māori protocol and to temporarily suspend dominant political, economic and cultural imperatives that are in many ways alien or hostile to what Māori assert as their identity. For Māori, a marae, particularly the one they belong to by birth, is a place of belonging.

11 Often, these thresholds are articulated by architectural elements, but not always: when a group of visitors is welcomed onto a marae and approaches the wharenui, there is a moment of pause, mid-way, which has always felt to me like a threshold changing my state of being. During powhiri (welcomes), though, the marae atea is sacred ground, whereas outside of ritual events, the same area can be used freely for children to play, to sit and talk and even to eat. In this state, the connections between marae atea and wharenui, outside and inside, are much more fluid.

12 "Not only their [indigenous Polynesians and Europeans'] views of the cosmos, but their entire conception of time and space were very different." (Tcherkézoff 2008b: 201) Amanda Yates suggests in Oceanic Grounds, "a dense interspersal of space and the event" is "familiar to Oceanic cultures", less so "to the traditions of Western thought and architecture" (Yates 2009: 12).

13 According to Sloterdijk, we share the womb with a twin: the placenta. It is, writes Rüdiger Saffranski, "living proof that each of us begins as two. Afterbirth follows birth." (1998) The placenta, once treated with great respect, was made abjected in Western modernity, thrown away or exploited for industrial purposes. "No respect is left for the companion of our earliest days." (Safranski 1998) Māori and Pacific people in Aotearoa, though, still bury the whenua (placenta) in the whenua (land).
There are some affinities between the relationship of wharenui and marae atea on a contemporary marae and European notions of a pacified interior versus an embattled exterior. ${ }^{10}$ The marae atea belongs to Tūmatauenga, the god and origin of war and conflict (Jahnke 2006: 139). When activated during encounters, it renders relationships potentially tense and volatile, and in need of sophisticated protocols to keep the danger of eruption at bay. By contrast, the interior of the wharenui is dedicated to Rongomātāne, the god of peace and cultivation (140). "To enter the house is to enter the poho, the bosom of an ancestor." (90) However, the division of inside-as-peaceful and outside-as-embattled is involuted: rather than pure exterior, the marae atea is already inside a complex of settlement. No absolute demarcation exists - instead, a series of transitional zones negotiate interior and exterior: the waha roa (entrance gate), the paepae kaiāwhā (the threshold to the porch) and the paepae a waha (the inner door-sill). Each threshold constitutes a critical zone of interaction, strategically positioning hosts and guests, so that their presence and transition has to be negotiated to establish "protocols for the interface" (Jahnke 1999: 193, 200). ${ }^{11}$

An early example of protocols for transitional zones was recorded in 1849 by Cuthbert Clarke. A party journeying with Te Heu Heu Iwikau and Governor Grey observed a young man in Matamata, who was expelled from the settlement and had to "remain outside the fence day and night". The man would sometimes "lean over the fence to listen to what was going on inside, looking on with ... a wistful air" (Frame 2002: 42). 'Locking-out' seemed cruel, locking-in normal to Grey. By contrast, Māori were horrified by the "caging of offenders" (44). Frame suggests that 'locking-out' would have been of little consequence to urban Europeans at that time, but it could have traumatic effects for Māori (44). Such effects were underpinned by different notions of self, communality and world. Today, in the seemingly similar exclusivity of gated communities, those shut out usually have no connections with those inside, no right of birth, and those inside no connection amongst themselves except the desire and the means to be insulated from others.

\section{The faletele and the circle of Fa'amatai}

These bounded and internally differentiated spaces are articulated very differently from spaces in Samoa. A European inability to conceptualise Polynesian space has been a major source of intercultural misunderstanding, principally because in Samoa "space is indissolubly linked to time" (Tcherkézoff 2008b: 136). ${ }^{12}$ The Samoan fale, like the wharenui, houses the ancestors - who "inhabit everything, everywhere, simultaneously" (Refiti 2009: 9). This notion of "everything, everywhere, simultaneously" connects past and present locations in and around the Pacific.

The ocean is, or is like, the $v \bar{a}$, an "opening, a gap or in-between place" which multiplies and con-fuses people and things (Ponifasio \& Refiti 2006). As a network of relations encompassing the world, the $v \bar{a}$ is "a way of thinking about space", "influencing interactions in everyday life", governing individual and group behaviour, "food division and distribution, sleeping and sitting arrangements, and language usage" in public and in private spaces (Lilomaiava-Doktor 2004: 200). Vā is constituted by a back-and-forth movement of curiosity and disclosure (Shore 2011). In Samoa, $v \bar{a}$ relations are reflected in the seating plan of the fono, the meeting of $m a-$ tai (family chiefs), where "everything is somehow seen in terms of relations, nothing in terms of things" (Tcherkézoff 2008a: 276). Vā is "a space-event or co-openness, located at the centre of every gathering, every sociality, [which] structures Samoan identity" (Refiti 2009: 10). Fale means not only "house" but also "inside" and falefale translates as "placenta". ${ }^{13}$ Still, a fale's interior until the 1960 s was 
not primarily a place of intimacy but much more a "formal public space" which is owned not privately but by the aiga (family) (Tcherkézoff 2008b: 161, 282).

Like other fale Samoa, the faletele (council house) in its classical form has no walls and no internal partitions. The clearly differentiated positions of matai in the fono circle are materialised in the posts supporting the roof of the faletele, over a circular base. Activating the $v \bar{a}$, this intense opening inward, the co-openness towards the ancestors, makes place for the networks of coexistence related to a particular house. ${ }^{14}$ What is most interior here is also most public: a gaze inhabits "the centre of social space and exposes and discloses the being of tagata (human)" (Refiti 2009: 11). In its light (emanating from the interior rather than the outside), people and things are exposed (13). In the faletele,

interiority becomes externalised, everything is drawn towards, and exposed in, this grand internal openness. However, this interiority is externalised again: space does not recede into an interior but is thrown back onto the surface of the world. Points (mata) alone fashion the plan of the house: they are the posts that denote ancestors and become the generator of space. (11)

Here, then, is a sense of interiority that seems diametrically opposed to that European notion of withdrawn-ness, Innerlichkeit, in which individuals collect the world around themselves, secreted and separated. However, houses in Samoa have changed over the last decades and walls are multiplying, along with new materials and private ownership. These changes to the central element of Samoan relationships, the fale, signal fundamental social changes (Tcherkézoff 2008a: 281-3).

\section{Interpreting the In: the work of the local}

In Aotearoa, contemporary Māori and Pacific architects bring Western and Oceanic concepts into dialogue, breaching the boundaries enclosing Western architectural discourse in its disciplinary and cultural containers. Interior, performance and landscape design - with their greater sensitivity to time - have affinity with the "temporalised built environments of Oceania whose mutable and porous spaces express changing conditions of interiority and exteriority". They establish fields of change and exchange in "fluid open spaces and transient breathing architectures" (Yates 2009: 72). In tropical and subtropical climates, buildings can be co-extensive with their environment, creating different sensory scenarios: "wind announces itself by rustling the outer layers of the walls and roof while the air remains still inside". The "soft bounce of the floor and gently filtered light", and "the faint smells of the materials" alert the senses to their connection with the surroundings (Hoskins \& Wilson quoted in Yates 2009: 32). Inside and outside are blurred, their boundaries rendered fluid (Yates 2009: 12, 94). Such architects, educated according to Western-style concerns but simultaneously familiar with Māori and Pacific knowledges and practices, shift across these cultural registers to creatively draw on both. They maintain and develop a locally specific notion of being-in.

Sloterdijk, too, has written of a "reciprocal belonging between a place and its inhabitant” (2005: 231); relationships between spaces and people are always reciprocal and dynamic. One of the great strengths of Sloterdijk's books discussed here is their rearticulation of European perceptions of interior and exterior, the boundaries between them, and the different notions of 'self' that individuals or groups may adhere to. Solidarity, the close togetherness of human beings and their ability to

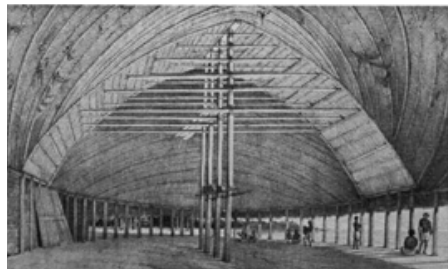

"Interieur de la maison publique d'Apia", drawing by Goupil; lithograph by P. Blanchard, 1848
14 Very important events may take place on the malae, rather than inside. Shore recalls how the "malae became like the floor of a great house. And each house that encircled the village green became like one of the house posts that framed the meetinghouse and at which chiefs usually took up their stations." (1996: 378) 
say "we", creates interior spaces as spheres (Sloterdijk, 1998: 14; 2005: 403). MitSein is "always being-alongside-others in a dwelling that has been built and in which we are enclosed. Being-with is always being inside of a dwelling” (Elden \& Mendieta 2009: 6). This leads Sloterdijk to make explicit architects' (and interior designers') role in Mit-Sein: they interpret, in "their own way, ... this most enigmatic of all spatial prepositions, namely the 'in'” (2009). They make statements on the relationship between "the world as apartment and the world as agora" (2009). That Sloterdijk has little to say about contemporary non-European spaces is understandable for someone living in Europe. More problematic is his defaulting to the universalising tendency of much European theory. The pairing of apartment and sports stadium as spaces of co-existence may be a useful paradigm for the analysis of space in modern mega-cities in the USA and Asia. It is less useful in other contexts. Ignored are even successful collective spaces in European cities, such as parks, street cafes and squares (see Schöttker 2011: 13).

Sloterdijk's texts are utterly stimulating, and his use of references is lavish and astounding. However, ultimately, he is held captive by his own language, his own sphere of influence and knowledge, his own "staunch fortress" into which other cultures and perspectives only ever have limited access. The weight of the existing creates blind spots in us all, and our own internalised understandings will always command centre stage unless we make the renovation of limits and boundarywork a habit.

Perhaps Sloterdijk's shortfall outside his European context rests on omission, not commission - at least in the texts discussed here. Given the lack of direct 'friction' with exterior (non-European) interiors, his views brush over many alternate meanings and configurations that "the interior" - an historically and culturally specific construct - has elsewhere. In an ecstatic Mit-Sein, the task ahead in Aotearoa/New Zealand is to articulate what "in" and "with" may mean here, and how these spatial relationships may interact with, impact on, and change Sloterdijk's assertions. At stake is an expanding and strengthening of the co-relations and co-production of interior and exterior states, and a re-discovery of the public and the multiple in the interior.

The last words are Sloterdijk's: "In human relationships, speaking and building usually create sufficient security ... now and then [to] permit ecstasy.” (2009) 


\section{References}

Alford, C. F. (2002). The Opposite of Totality: Levinas and the Frankfurt School. Theory and Society, 31(2), 229-254.

Austin, M. (2004). Pacific Island Migration. In S. Cairns (Ed.), Drifting: Architecture and Migrancy (pp. 224-238). London: Routledge.

Bachelard, G. (1969). The Poetics of Space (M. Jolas, Trans.). Boston: Beacon Press.

Benjamin, W. (2002). The Arcades Project (H. Eiland \& K. McLaughlin, Trans.). Cambridge (Mass.): Harvard University Press.

Chow, R. (1993). Writing Diaspora: Tactics of Intervention in Contemporary Cultural Studies.

Bloomington: Indiana University Press.

Cohen, D. (2006). Household Gods: The British and Their Possessions. New Haven:

Yale University Press.

Couture, J.-P. (2009). Spacing Emancipation? Or How Spherology Can Be Seen as a Therapy for Modernity. Environment and Planning D: Society and Space, 27, 157-163.

Elden, S., \& Mendieta, E. (2009). Being-with as Making Worlds: The 'Second Coming' of Peter Sloterdijk. Environment and planning D: society and space., 27(1), 1-11.

Frame, A. (2002). Grey and Iwikau - a Journey into Custom. Kerei Raua Ko Iwikau - Te Haerenga Me Nga Tikanga. Wellington: Victoria University Press.

Funke, D. (2006). Die dritte Haut. Psychoanalyse des Wohnens. Giessen: Psychosozial-Verlag.

Gunning, T. (2003). The Exterior as Interieur: Benjamin's Optical Detective. Boundary, 30(1), 105.

Günzel, S. (2005). Philosophie und Räumlichkeit. In F. KessI \& C. Reutlinger (Eds.), Handbuch Sozialraum (pp. 89-110). Wiesbaden: VS Verlag für Sozialwissenschaften.

Harrison, P. (1988). Tane-Nui-a-Rangi. Auckland: University of Auckland.

Jahnke, R. H. G. (1999). Voices Beyond the Pae. In N. Thomas, D. Losche \& J. Newell (Eds.), Double Vision: Art Histories and Colonial Histories in the Pacific (193-209). Cambridge: Cambridge University. Jahnke, R. H. G. (2006). He Tataitanga Ahua Toi: The House That Riwai Built, a Continuum of Māori Art. Unpublished Doctor of Philosophy, Massey University, Palmerston North.

Kähler, G. (1990). Innen Welt / Inner World. Daidalos(36), 30-41.

Kroeber-Wolf, G., \& Mesenhöller, P. (1998). Talofa! Samoa, Südsee - Ansichten und Einsichten. Frankfurt: Museum für Völkerkunde.

Lilomaiava-Doktor, S. (2004). Fa'a-Samoa and Population Movement from the Inside Out: The Case of Salelologa. University of Hawai i.

Mackenzie, K., \& Bennett, M. (Writer) (2011). The village. In S. P. Megan Douglas (Producer), Whare Māori. Aotearoa: Māori Television.

Mackenzie, K., \& Bennett, M. (Writer) (2011). The wharenui (part one). In S. P. Megan Douglas (Producer), Whare Māori. Aotearoa: Māori Television.

Milligan, A., Hollis, E., Milton, A., Plunkett, D., Hay, F., \& Gigli, J. (2007). Rethinking inside the Box: Reflections on the Interiors Forum Scotland 2007 Conference. IDEA, 16-37.

Mönninger, M. (2009). Laudatio. BDA-Preis für Architekturkritik für Peter Sloterdijk. 20 June 2009, Weimar. Retrieved 28 September, 2010, from http://www.bda-bund.de/fileadmin/ mediaFiles/Bundesverband/Moenninger_Laudatio.pdf

Nancy, J.-L. (2007). Urbis et Orbi (F. Raffoul \& D. Pettigrew, Trans.). In The Creation of the World or Globalization (pp. 31-56). New York: State University of New York Press.

Perrot, M. (Ed.). (1990). A History of Private Life. From the Fires of Revolution to the Great War. Cambridge (Mass.): Harvard University Press.

Ponifasio, L., \& Refiti, A. (2006). Vasa. A Collaborative Project of Lemi Ponifasio and Albert Refiti. March 23 - April 14, 2006. Retrieved 12 September, 2009, from http://www.aut.ac.nz/study-at-aut/ study-areas/art-design/learning-environment/st-paul-street-gallery/exhibition-2006/march/vasa Rabinow, P. (Ed.). (1991). The Foucault Reader. London: Penguin.

Refiti, A. L. (2009). Whiteness, Smoothing and the Origin of Samoan Architecture. Interstices: Journal of Architecture and Related Arts (10, Adam's House in Paradise), 9-19.

Safranski, R. (1998). Der Nabel der Welt. Der Spiege/ (45). Retrieved 14 June, 2008, from http:// www.spiegel.de/spiegel/print/d-7000922.html

Schöttker, D. (2011). Architekturtheorie zwischen Gesellschafts-und Kulturtheorie. Von Adorno zu Sloterdijk. Leviathan, 39(1), 3-19.

Shore, B. (1996). Culture in Mind: Cognition, Culture, and the Problem of Meaning. New York: Oxford University Press.

Shore, B. (2011, 4-8 July). Samoan Shorelines: Forty Years of Returning to Samoa. Paper presented at the Samoa Conference II: Tracing Footprints of Tomorrow: past lessons, present stories, future lives, Apia, National University of Samoa.

Sloterdijk, P. (1998). Sphären I: Blasen (Vol. 1). Frankfurt a.M.: Suhrkamp. 
Sloterdijk, P. (1999a). Der gesprengte Behälter. Notiz über die Krise des Heimatbegriffs in der globalisierten Welt. Der Spiegel, (6 - Spezial: Sehnsucht nach Heimat), 24-29. Retrieved 27 October, 2009, from http://www.spiegel.de/spiegel/spiegelspecial/d-13536502.html

Sloterdijk, P. (1999b). Sphären Il: Globen (Makrosphärologie) [Spheres II-Globes, MacroSpherology] (Vol. 2). Frankfurt am Main: Suhrkamp.

Sloterdijk, P. (2004). Sphären III: Schäume [Spheres III: Foams] (Vol. 3). Frankfurt am Main: Suhrkamp.

Sloterdijk, P. (2005). Im Weltinnenraum des Kapitals. Frankfurt: Suhrkamp.

Sloterdijk, P. (2009). Spheres Theory - Talking to Myself About the Poetics of Space. Harvard Design Magazine, 1 Culture + Architecture(30 Sustainability + Pleasure). Retrieved 27 October, 2009, from www.gsd.harvard.edu/events/pdf/Peter_Sloterdijk.pdf

Sloterdijk, P., \& Royoux, J.-C. (2005). Foreword to the Theory of Spheres. In M. Ohanian \& J.-C. Royoux (Eds.), Cosmograms. New York: Lukas \& Sternberg. Retrieved 27 October, 2009, from http://www.sed.manchester.ac.uk/research/marc/news/seminars/latour/COSMOGRAM-INTERGB_Spheres.pdf

Tcherkézoff, S. (2008a). Culture, Nation, Society. In T. Serge \& D.-M. Françoise (Eds.), The Changing South Pacific. Identities and Transformations (245-301). Canberra: ANU Press. Retrieved 17 October, 2011, from http://epress.anu.edu.au/csp/pdf/whole_book.pdf

Tcherkézoff, S. (2008b). First Contacts in Polynesia-the Samoan Case (1722-1848): Western Misunderstandings About Sexuality and Divinity. Canberra: Anu E Press.

ten Bos, R. (2009). Towards an Amphibious Anthropology: Water and Peter Sloterdijk. Environment and Planning D: Society and Space, 27,73-86.

Thrift, N. (2009). Different Atmospheres: Of Sloterdijk, China, and Site. Environment and Planning D: Society and Space, 27(1), 119-138.

Tui Atua Tupua Tamasese Ef (2007, 29 October). Samoan Jurisprudence and the Samoan Lands and Titles Court: The Perspective of a Litigant. Paper presented at the University of Hawaii, Manoa, Apia. Retrieved 11 November, 2010, from http://www.head-of-state-samoa.ws/pages/ speech_jurisprudence.html

Wittgenstein, L. (1958). Philosophical Investigations. Philosophische Untersuchungen (2nd ed.). Oxford: Basil Blackwell.

Wollen, P. (1993). Theme Park and Variations. Sight and Sound, 3(7), 7-9.

Yates, A. (2009). Oceanic Grounds, Architecture, the Evental and the in-Between. Unpublished Masters Thesis, Massey University, Wellington. 